Mária Czellér - Zita Hajdu

\title{
Incorporating Blended Learning in Teaching English for Specific Purposes
}

\author{
Czellér Mária - Hajdu Zita: A blended learning módszer alkalmazása a szaknyelv-oktatásban \\ Összefoglaló \\ Az informatika és az Internet alkalmazása új perspektívát nyit meg az idegen nyelvek oktatása \\ terén. A tanulmány célja, hogy bemutassa, hogyan lehet az internetet hatékonyan alkalmazni a \\ szaknyelvoktatásban. A nyelvoktatási módszerek történetének rövid áttekintése után ismertetjük \\ azt a blended learning módszerre épülö nyelvoktatási projektet, amely a Debreceni Egyetemen \\ folyik. Megvizsgáljuk továbbá, hogy az információs technika és a tantermi oktatás \\ kombinációjával miként válik érdekessé és inspirálóvá a nyelvtanulás folyamata.
}

Kulcsszavak: nyelvoktatási módszerek, blended learning, Internet, szaknyelv, szervezeti sikeresség

\begin{abstract}
As a result of the prevalent use of the Internet, teaching foreign languages can get a new perspective. This paper presents how teachers can incorporate the Internet in teaching English for specific purposes. First, a brief historical background of language learning methods is given, and then the focus shifts to a new language learning project applying blended learning at the University of Debrecen. The paper also shows how traditional classroom activities can be combined with online methods to make language learning more enjoyable.
\end{abstract}

Key words: language learning methods, blended learning, Internet, ESP, company success

\section{INTRODUCTION}

Today's world of globalisation, along with the prevailing effects of new information and communication technologies, have thrown new light on foreign language skills and thus the role and methods of foreign language teaching. The content and methods of foreign language education have always reflected the actual historical period. Bearing in mind the motto of the present conference "Tell the antecedents, know the present, and foretell the future," the history of foreign language teaching methods, the present situation and prospective tendencies are all worth being investigated.

\section{REVIEWING THE PAST}

The first foreign language training method applied for the teaching of Ancient Greek and Latin languages in the 18th century was based on grammar and translation. Foreign language education was focused on translation supplemented by grammar drills and exercises. Mastering these dead languages did not require the improvement of language use.

The direct method introduced at the end of the 19th century concentrated on living languages, the mother tongue was excluded from the teaching process, and the emphasis was placed on phonetics.

The Second World War initiated a new method, as military necessities demanded the rapid acquisition of a foreign language, which generated the intensive or Army Method. In the 20th century, plenty of methods were tested. The audio-lingual approach of the 1950s was rooted in the dominant psychological trend of the decade, behaviourism and was also strongly 
related to structural linguistics. Language learning was interpreted as the process of making habits routine-like, which lead to classes full of drills and confirmations. In chronological order, the cognitive technique, also known as the mentalist trend, dominated the next stage. Chomsky's generative linguistics and cognitive psychology provided its background and emphasis was placed on learning from mistakes and finding rules.

Demand for a communicative approach aiming at training people with a high level of communication skills appeared in the 1960s and 1970s. The communicative approach introduced the development of the four skills of foreign language knowledge as the foci of language training. This method plays a crucial role in today's language teaching, as well.

Obviously, alternative methods did not avoid language training, either. Although some of these (e.g.: suggestopaedia, the silent way, counselling-learning) ran parallel with one another in the 1970s, none have become widespread. Indeed, several other minor methods which have never become popular could be mentioned. However, the major elements of the following four approaches are still widely used (Bárdos 2004: 17): the grammar-translation method, the direct method, the behaviourism based audio-lingual method and the mentalist method, which is effective in technical language teaching. Today, it is recognized that a combination of best practices integrating several methods may bring the greatest L2 learning successes. Similarly, Wiwczaroski (2009:1-6) discusses the "unique integration of research, subject and language teaching methodologies with the need to develop critical thinking in the learner, in order to ensure that outcomes are cognitively challenging ... which will sustain the evolution of the gained multiple focused learning and research processes."

\section{THE IT-BASED PRESENT}

The use of computers and the Internet shape our century, and they inform the processes of pedagogy and language learning to an ever greater degree. Instead of textbooks and workbooks, these instruments have become the means of study for young people referred to as the "thumb generation". In North America, textbooks are already designed for iPads. Students simply download the curriculum; they can even enter notes with the help of special assistance programs. Students keep in touch with friends, share photos and videos on Facebook, which has become a major channel of communication, the second Internet.

Due to the application of new technologies, computers as the new medium of our society have opened a new dimension of studying. Information systems allow for the virtual departure from the classroom or finding authentic and topical teaching resources in the target language. The traditional role of the teacher is reconsidered; transforming teachers transmitting knowledge into moderators helping students become conversant with virtual space. Language teaching also has to move with the times, and modern technology and its methods need to be adjusted to the expectations of the age. The tool treasury of language teaching is constantly being enriched by the Internet, at the same time allowing for the application of new language training methods.

\section{THE BLENDED LEARNING METHOD}

With information technology becoming increasingly advanced, a growing number of foreign language teachers have started to use online materials in their teaching programs. This has led to the emergence of a relatively new method called blended learning, most commonly defined as the strategic combination of online and face-to-face learning experiences and instructions. (Reay 2001: 1-6). One of the most important aspects of Internet-based language tuition is its up-to-date vocabulary.

The present paper addresses the practices of language teachers in applying the method of blended learning in teaching English to students 
majoring in economic sciences using the MOODLE platform that allows for downloading materials prepared for this purpose.

\section{CHANGES IN THE CONTENT - TECHNICAL LANGUAGE SKILLS}

New demands in the economy and society have ushered in changes in the content of education. While the grammar-translation method was mainly based on translating pieces of literature, today's language tuition places the focal point on Office English or Business English when teaching students or adults.

Foreign language competencies play an essential role in the internal and external communication of transnational or multinational organisations and in the foreign affairs of any organisation.

In the past century, several research projects aimed at determining the role of foreign language competencies in sales growth (Embleton-Hagen 1992: 22-23) or dealt with the influence of the foreign language proficiency of a potential workforce on choosing new corporate sites. The findings proved that fluent corporate communication is a precondition for smooth and effective company operations.

In the present millennium, the institutions of the European Union have been investigating the effects of foreign language skills on company performance among small enterprises with less than fifty employees (Hassid 2002: 5874). The European Centre for the Development of Vocational Training conducted a research project in seven European countries asking businesses about the success factors and difficulties of their international activities. More than half of the participating enterprises agreed that international activity is more difficult than domestic trade. From among purely languagerelated factors hindering foreign trade, oral communication proved to be the most serious problem. In addition, there were several other difficulties which cannot be eliminated without acquisition of foreign language proficiency: arranging delayed payments (12\%), acquiring market information (15\%), access to markets (17\%), the establishment and maintenance of business contacts and networks (19\%). (Figure 1.).

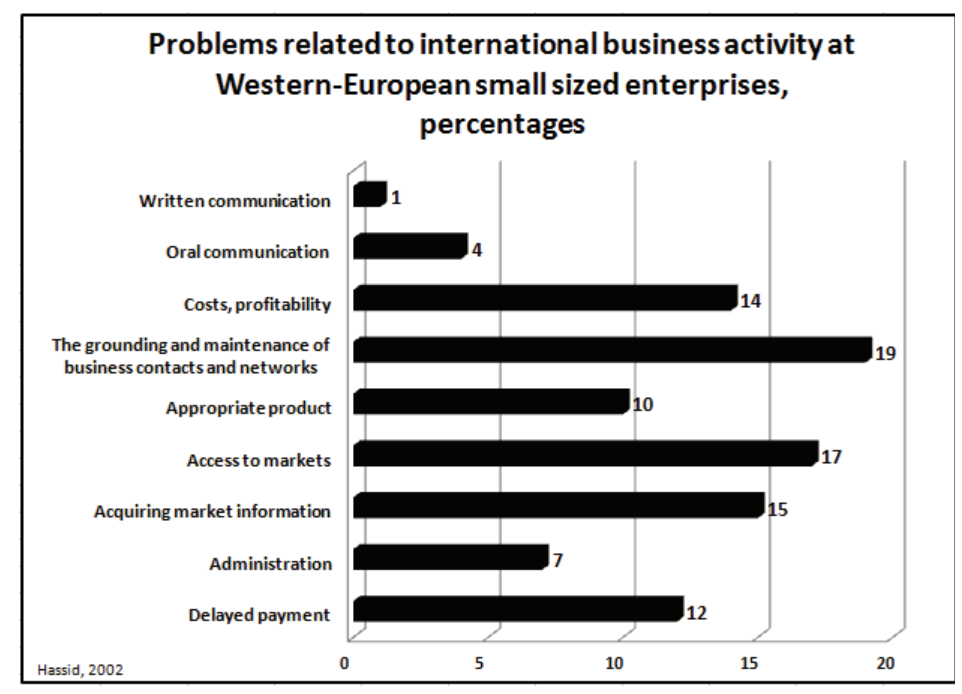

Figure 1.

Problems related to international business activity at Western-European small sized enterprises, percentages (Hassid 2002:67) 
Business organisations involved in foreign trade also benefit from meeting the latest technologies and innovations. According to $10 \%$ of the surveyed businesses, the language proficiency of the staff of an enterprise influences the selection of the potential export markets as well. Eighteen percent of the questioned enterprises experienced cooperation problems due to cultural differences.

Regarding the need for foreign language competencies, Hungarian business managers share the opinion of their European companions. In a survey completed by the Hungarian Chamber of Industry and Commerce, company managers and human resources executives ranked the importance of foreign language skills for recent graduates as 4.52 on a scale between 1 and 5 , but their actual language knowledge was only scored at 3.78, on average. The shortcomings in these competencies, particularly in technical language skills, have still been among the most common reasons for failure in the employee selection process (Selmeczy 2006: 27-38., 4044., 51-52.).

\section{INSTITUTIONAL BACKGROUND}

Based on the outcomes of the abovementioned examinations, one can establish that there is an unfulfilled need in the labour market concerning foreign language knowledge, and universities are expected to react.

In Hungary, it is up to individual universities to decide whether they regard it as important and effective to include language teaching in their study programmes. Furthermore, it is the right of higher education institutions, albeit also their responsibility, to determine the number and aim of foreign language courses they will possibly offer. As Wiwczaroski notes, "The consequences of the indecision surrounding the role of foreign language teaching in Hungarian higher education are that the level of L2 competence in Hungary remains... low in comparison with those of other EU countries."(Wiwczaroski 2005:1-11) There is no unified strategy and this is problematic. Indeed, the range of language training programmes at Hungarian universities varies considerably. Although universities have autonomy to decide on their own language programmes, the degree requirements towards foreign languages are determined at a national level. Due to these requirements, graduates cannot receive their degree without a successful completion of a foreign language examination certified by an accredited institution. Depending on the field of study, the required focus can be general language or language for specific purposes.

The University of Debrecen integrates foreign language teaching into the degree programmes, and its main mission is to prepare students for the relevant state language examination as well as for the requirements of the international labour market.

The present foreign language training project at the University of Debrecen intends to meet the needs of the labour market. "Szaknyelv-tudás" - $A z$ idegen nyelvi képzési rendszer fejlesztése a Debreceni Egyetemen (TÁMOP 4.1.2.D-12/1/KONYV-2012-0008. "Technical language skills" - Improving foreign language training programs at the University of Debrecen) (http://szaknyelvtudas.unideb.hu).

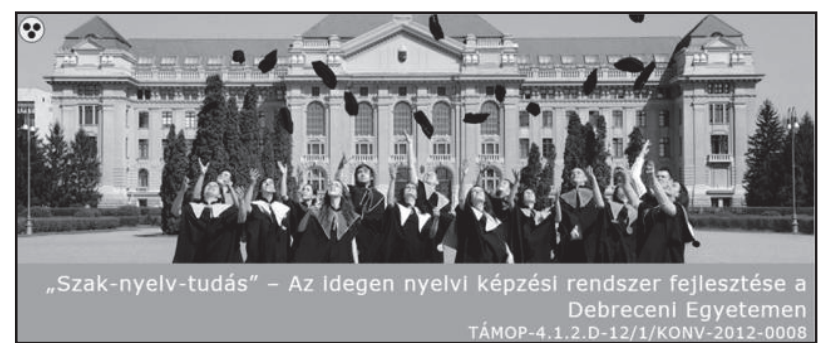

Figure 2. The opening page of the project (http://szaknyelvtudas.unideb.hu) 


\section{THE PROJECT}

\subsection{Goals}

The project aims to renew the foreign language training of students at the University of Debrecen. On the one hand, the objective is to reach the language competence levels expected by the job market while, on the other hand, developing a language teaching program which is adjusted to the new learning routines of the students, at the same time harnessing the advantages of blended learning.

Reforming the content and methodology of technical language tuition and developing an up-to-date teaching material package for ESP students were significant sub-goals of the project. To reflect labour market expectations, a strong and on-going cooperation has been formed with the most important employers of the North Great Plain Region, the key economic partners of Debrecen University and national trade associations.

A team was in charge of developing the curriculum by involving actors of the job market in designing the syllabus. With respect to the content of the curriculum, several meetings involving a pooling of experience took place with representatives of companies in Debrecen; primarily with executives and managers involved in conducting job interviews and making decisions on employment, e.g.: the Hajdú-Bihar County Chamber of Industry and Commerce, the Employment Centre of HajdúBihar County and most importantly multinational companies such as IT Services Hungary Ltd., National Instruments, the Teva Pharmaceutical Works Ltd., FAG Hungary Ltd., KITE Agricultural, Commercial and Service Ltd. Apart from these, workshops were organised in professional fields to harmonize the content with employers' wishes.

With the active participation of one particular key partner at each workshop and chaired by the labour market coordinator this series of events served to identify training needs and determine the most serious problems experienced by employers.

On compiling the curriculum for the oral materials, communication situations arising in multinational environments or at companies with foreign operations were considered. Job interviews, meetings in foreign languages and other everyday situations were also included. Frequently used genres and types of written communication of business environments were also taken into account, e.g.: Application forms, CVs, Personal Statements, Letter of Application, Letter of Enquiry, Letter of Complaint, Information giving letters, Memos, Emails, Descriptive compositions, Narrative compositions, Discursive compositions.

For the reading comprehension tasks, standard question and task formats used in language exams were applied: True/False, Short answers to questions, Matching clauses to gaps in the text, Matching headings to paragraphs, Summary, Open gap-filling, Banked gap-filling, Multiple choice.

Although employers' opinions took precedence, student demands were also kept in mind. Interactive learning opportunities (online resources and curricula, blended techniques) are increasingly attractive and therefore more effective with students. Accordingly, we intended to utilize the multimedia possibilities offered by the Internet and other up-to-date web technologies, mixing them with traditional classroom tuition. The Internet allows for the finding of authentic and topical information: texts, pictures and diagrams. A great deal of our curriculum is founded on topical Internet resources, either by having the text built into the unit or providing a collection of links which helps the students find further readings or gather useful and relevant information in a particular field of study. Another option is including an Internet resource in the home assignment.

\section{2. Aspects for compiling the curriculum:}

Presenting topics most important in the world of work, vocabulary development (Writing a CV, Finding a job, Mobility, Place of work, Progress at work, Customer Service).

- Improving written and oral communication skills expected in the labour market. 
- Developing competencies evaluated at language exams. (Origo, Zöld Út, DExam, Kitex, Euroexam, IELTS etc.) and

- Demonstrating and practising task types occurring at language exams.

- Motivating students with online materials.

- Introducing Internet resources for language practice and information acquisition to students' e.g.: online dictionaries, information services (BBC, Wikipedia).

\subsection{The structure}

The above described aspects provided the basis for the 10 units of the written and oral material, respectively (Figure 3. and 4.):

Unit 1. Finding a job

Unit 2. Mobility

Unit 3. Place of work

Unit 4. Progress at work
Unit 5. Working life and health

Unit 6. IT

Unit 7. Jobs in entertainment, media and PR

Unit 8. Travelling on business

Unit 9. Customer service

Unit 10. Environmental issues

Unit 1 Preparing for working life

Unit 2 The ideal job - What job is best for you?

Unit 3 Job interviews

Unit 4 On the job

Unit 5 Healthy lifestyle - stress at work

Unit 6 Socializing in the workplace

Unit 7 Company guests and visitors

Unit 8 Team building

Unit 9 Travelling on business

Unit 10 Company training

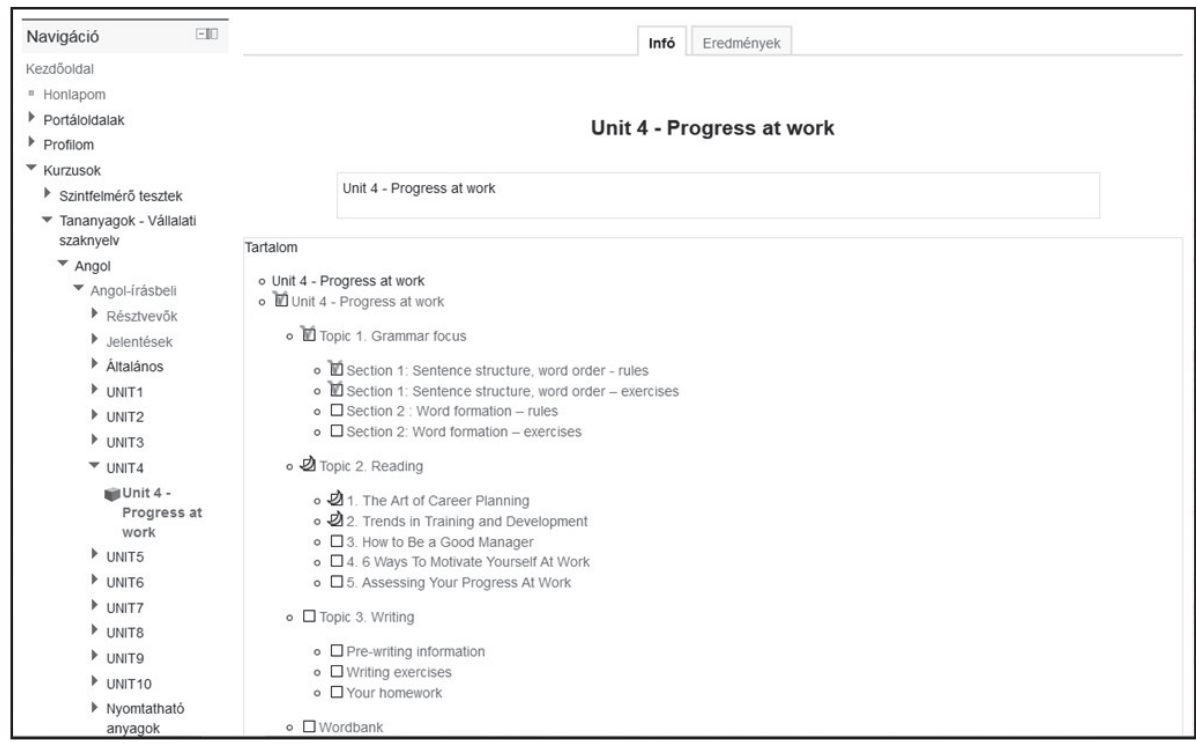

Figure 3. The syllabus of a unit in the written part of the program (http://szaknyelvtudas.unideb.hu) 
Teaching languages for specific purposes (LSP)

\begin{tabular}{|c|c|c|c|}
\hline $\begin{array}{l}\text { Angol-szóbeli } \\
\text { Résztvevō̌k } \\
\text { J Jelentések } \\
\text { Általános } \\
\text { - Unit } 1 \text { - Preparing } \\
\text { for working life }\end{array}$ & 1 & $\begin{array}{l}\text { Unit } 1 \text { - Preparing for working life } \\
\text { Unit } 1 \text { - Preparing for working life } \\
\text { Unit } 1 \text { - Preparing for working life } \\
\text { Listening } 1 \\
\text { Listening } 2\end{array}$ & $\square$ \\
\hline $\begin{array}{l}\text { Unit } 2 \text { - The ideal } \\
\text { job - What job is } \\
\text { best for you? } \\
\text { Unit } 3 \text { - Job } \\
\text { interviews } \\
\text { Unit } 4 \text { - On the job } \\
\text { Unit } 5 \text { - How to } \\
\text { relieve stress } \\
\text { Unit } 6 \text { - Socializing } \\
\text { in the workplace } \\
\text { Unit } 7 \text { - Company }\end{array}$ & 2 & $\begin{array}{l}\text { Unit } 2 \text { - The ideal job - What job is best for you? } \\
\text { Unit } 2 \text { - The ideal job - What job is best for you? } \\
\text { Unit } 2 \text { - The ideal job - What job is best for you? } \\
\text { Listening1 } \\
\text { Listening2 } \\
\text { Listening3 } \\
\text { Listening4 } \\
\text { Listening5 }\end{array}$ & $\square$ \\
\hline $\begin{array}{l}\text { Unit } 8 \text { - Team } \\
\text { building } \\
\text { Unit } 9 \text { - Travelling } \\
\text { on business } \\
\text { Német }\end{array}$ & 3 & $\begin{array}{l}\text { Unit } 3 \text { - Job interviews } \\
\text { Unit } 3 \text { - Job interviews } \\
\text { Unit } 3 \text { - Job interview } \\
\text { Listening1 } \\
\text { Listening2 }\end{array}$ & $\square$ \\
\hline
\end{tabular}

Figure 4. The syllabus of the oral part of the program (http://szaknyelvtudas.unideb.hu)

\subsection{Stages of implementation}

The curriculum was uploaded into the Moodle system and taught in Pilot courses, which proved to be one of the most important elements of the project. The target groups of the Pilot trainings were students in government financed courses and students who have not satisfied the degree criteria concerning language exams. The goal was to upgrade student proficiency level to CEFR B2 from CEFR B1. Pilot courses were organised as 60-classcourses within the framework of the university training programs, the course instructors are the language teachers of the university. During the implementation stage, attention is given especially to measuring student performance upon entering and leaving the program. Study groups are formed on the basis of placement tests, in order to have students with more or less homogenous language proficiency levels together in the classroom.

\subsection{Students' opinion}

Students are addicted to the Internet; they are online almost all day, sending messages and posts on Facebook. Should they need any information, they will not look it up in an encyclopaedia, telephone directory or timetable, but in a search program on the Net.
Accordingly, it is no surprise that they welcome an online curriculum. One aspect of its attraction is its novelty, as this kind of language teaching has not become widespread. When launching the courses, we asked students if they had used online teaching programs in their secondary schools and almost all their replies were negative. They were also asked how they feel about this method of teaching, and the following answers were received: it is an easier way of learning; they have access to the material anytime; it is easy to handle; classes are more colourful, diverse, varied and enjoyable; the rhythm of the classes is faster; we do not need to write with a pen; it is easier to learn a language with the help of the computer; the program corrects the answers immediately; a lot of interesting pictures are available for picture description; the quality of the listening tasks is always good; we find it easier to concentrate on the tasks as we don't have to take notes; we can choose from several different types of tasks; online dictionaries are always available; I can follow the material from home as well; it is more enjoyable than a book; simple and easy to handle; it promotes language improvemen; it provides useful skills for everyday life; more interesting and graphic than books (Figure 5.). These opinions show 
that students are open to accepting the new method and are therefore more motivated and active in language classes.

In summary, we can say that the application of online teaching materials is interesting and inspiring for the language learner and an excellent opportunity for improving language skills and getting familiar with most recent resources.
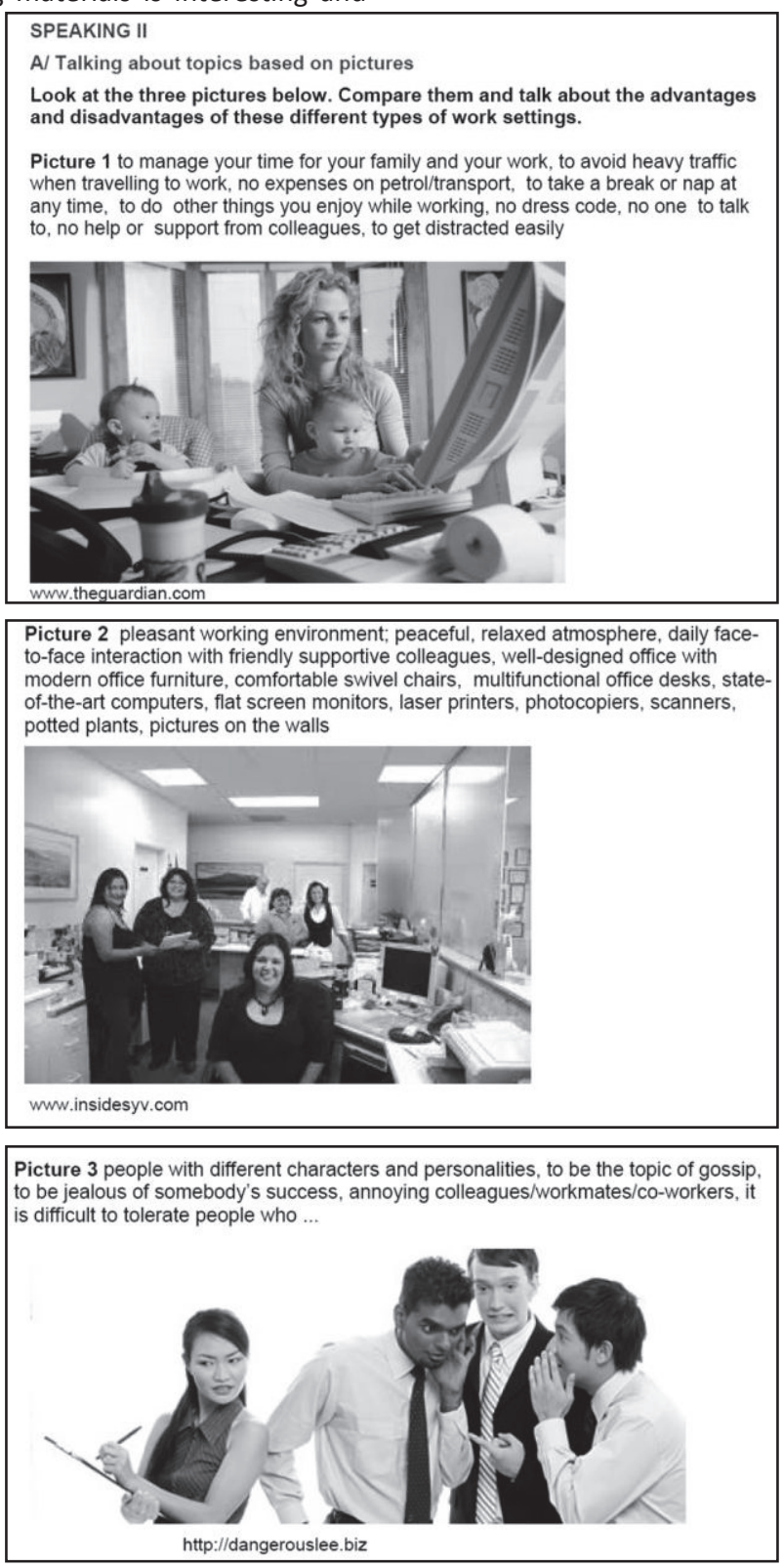

Figure 5. Pictures from the oral curriculum (http://szaknyelvtudas.unideb.hu) 


\section{CONCLUSION}

The application of informatics and the Internet offer endless possibilities in language teaching, but also present several methodological challenges for the foreign language teacher. The teacher must be informed about and skilled in informatics; he/she must know and be able to use informatics-based materials and, most crucially, be capable of preparing students to properly work with these materials.

University students routinely use digital instruments as a matter of course; therefore, the application of digital curricula is evident. We have always tried to make our lessons more interesting and colourful by including supplementary materials, such as real life situations, authentic texts, listening tasks and articles. Involving the Internet in resource collection does not alter this routine. One of the advantages of the Internet is that it can significantly simplify and modernise home preparation for the classes, assembling resources and item writing. At the same time, it enriches and updates the teachers' knowledge, as well.
New technologies will not exclude old ones, but those which proved to be time-honoured will be integrated and blended with the new techniques. Teaching Business English cannot omit grammar, but grammar structures are placed into business contexts by using authentic documents or extracts from documentaries or feature films.

Currently, the personality of a teacher is often not enough to give the lesson momentum, but information technology combined with classroom education can lead to outstanding results. It is the teacher's task to find the most suitable approach from the repository of language teaching methods.

Returning to the motto of the conference, we can say that computers will enjoy a prominent role in the future of language teaching, but probably - and hopefully - they will never take over the role of the teacher completely, as the personal relationship of the student and the teacher is essential in this learning process. This role makes it more flexible, more personal, and thus more real. We strongly believe that teachers will continue to play a vital role, even in an IT-dominated world.

\section{BIBLIOGRAPHY}

[1] Bárdos J. (2004): Nyelvpedagógiai tanulmányok, Iskolakultúra-könyvek 24. (szerk. Géczy J.), Pécs. 17. p.

[2] Embleton, D.-Hagen, S. (1992): Languages in International Business: A Practical Guide. Hodder \& Stoughton. London. 22-23. p.

[3] Hassid, J. (2002): Internationalisation and changing skill needs in European small firms. Cedefop Reference Series; 23. Luxembourg: Office for Official Publications of the European Communities. 58-74. p.

[4] Reay, J. (2001) Blended Learning: Fusion for the Future. Knowledge Management Review, 4 (3), 1-6. p.

[5] Selmeczy I. (2006): Az üzleti szféra felsőfokú végzettségű pályakezdők iránti kereslete, ennek várható alakulása és a pályakezdők tudásával való elégedettség 2005-ben. Magyar Kereskedelmi és Iparkamara Gazdaság- és Vállalkozáselemző Intézet. 13. http://www.gvi.hu/letoltes/ms/doc/dip_0601.doc 27-38., 40-44., 51-52. p.

[6] Wiwczaroski, Troy B. (2005): On the Effects of Globalization on ESP: A Thought Paper on Preparing a Place for Ourselves in Hungarian Higher Education. ESP World, Vol. 4, No. 2, 111. p. http://papers.ssrn.com/sol3/papers.cfm?abstract_id=874084

[7] Wiwczaroski, Troy B. (2009) Resistances and Barriers to the Introduction of CLIL Courses. ESP World 5 (26), Volume 8, 1-6. p. http://www.espworld.info/Articles_26/Original/Resistance.pdf 